\title{
Long term changes in community assembly, resistance, and resilience following experimental floods
}

\author{
Christopher T. Robinson ${ }^{1}$ \\ Department of Aquatic Ecology, Eawag, 8600 Duebendorf, Switzerland and Institute of Integrative Biology, \\ ETH Zürich, Zürich, Switzerland
}

\begin{abstract}
This study examined the long term changes in community assembly, resistance, and resilience of macroinvertebrates following 10 years of experimental floods in a flow regulated river. Physico chemistry, macroinvertebrates, and periphyton biomass were monitored before and sequentially after each of 22 floods, and drift/seston was collected during six separate floods over the study period. The floods reduced the density and taxon richness of macroinvertebrates, and a nonmetric dimensional scaling (NMDS) analysis distinguished temporal shifts in community assembly. Resistance (measured as the relative lack of loss in density) to floods varied among taxa, and the abundance of resistant taxa was related to the temporal changes in community assembly. Community resistance was inversely related to flood magnitude with all larger floods $\left(>25 \mathrm{~m}^{3} / \mathrm{s},>16\right.$ fold over baseflow) reducing densities by $>75 \%$ regardless of flood year, whereas smaller floods $\left(<20 \mathrm{~m}^{3} / \mathrm{s}\right)$ reduced taxon richness approximately twofold less than larger floods. No relationship was found between flood magnitude and the relative loss in periphyton biomass. Resilience was defined as the recovery slope (positive slope of a parameter with time following each flood) and was unrelated to shifts in community assembly or resistance. Macroinvertebrate drift and seston demonstrated hysteresis (i.e., a temporal response in parameter quantity with change in discharge) during each flood, although larger floods typically had two peaks in both parameters. The first peak was a response to the initial increases in flow, whereas the second peak was associated with streambed disturbance (substrate mobility) and side slope failure causing increased scour. Drift density was 39 times greater and that of seston 330 times greater during larger floods than smaller floods. These results demonstrate temporal shifts in macroinvertebrate community assembly toward a pre dam assemblage following sequential floods in this flow regulated river, thus confirming the ecological role of habitat filtering in organism distribution and abundance. Community resistance and resilience were unrelated to shifts in community assembly, suggesting that they are mostly evolutionary properties of ecosystems as populations adapt to changing environmental (disturbance regimes) and biotic (novel colonists) conditions. As these systems show behaviors similar to dispersal limited ecosystems, a long term perspective is required for management actions targeted toward regulated and fragmented rivers.
\end{abstract}

Key words: flow regime; large dams; macroinvertebrates; periphyton; regulated river; temporal.

\section{INTRODUCTION}

Most large rivers globally have been regulated to some degree with $>45000$ large dams currently in place for water storage, hydropower production, navigation, and flow regulation (Nilsson et al. 2005). The ecological consequences of these large dams are many, including fragmentation in river connectivity (Ward and Stanford 1979, 1995), isolation of riverine flora and fauna (Mueller 1995), alterations in the physical habitat template below dams (Graf 2006), and changes in biotic interactions and aquatic food webs (Power et al. 1996, Cardinale et al. 2005, Cross et al. 2011). Many of these ecological changes have been conceptualized earlier in

Manuscript received 28 June 2011; revised 20 April 2012; accepted 24 April 2012. Corresponding Editor: A. K. Ward.

${ }^{1}$ E mail: Robinson@eawag.ch the serial discontinuity concept that places rivers and their inhabitants in a holistic, landscape perspective that integrates the multidimensionality of intact rivers (Ward and Stanford 1983). A holistic, landscape perspective is imperative if ecologists and resource managers are to better understand and predict the effects of mitigation measures, e.g., adaptive management programs, on long term processes acting on river ecosystems. For instance, fragmentation in the river continuum by large dams constrains the dispersal of many aquatic organ isms, ranging from seed dispersal of riparian plants (Merritt and Wohl 2006, Bejarano et al. 2011), overland dispersal of aquatic insects during the adult winged stage (Monaghan et al. 2002), to instream movement of migratory shrimps, fishes, and mammals (Dudgeon 2000), with important implications regarding population sustainability and persistence. Indeed, dispersal limita tion may be a major constraint in mitigation measures 
contingent on the successful recolonization of rivers by organisms outside the system (Palmer et al. 1996), or even facilitate the biological invasion of the system (Johnson et al. 2008).

Floods and flow pulses are features of the natural flow regime of most unregulated rivers (Junk et al. 1989, Poff et al. 1997), and the natural flow regime has been highlighted as an important factor for inclusion in the management of flow regulated rivers (Poff et al. 1997, Arthington et al. 2006). Concomitantly with flow, the temperature regime also has been long recognized as a driving force in the habitat template of river ecosystems (Vannote et al. 1980, Vannote and Sweeney 1980), and both flow (Robinson and Uehlinger 2008, Cross et al. 2011, Melis 2011) and temperature (Olden and Naiman 2010) have been used in the management of regulated rivers with varying success. Floods, in particular, are important disturbance events influencing the eco evolu tionary adaptations of freshwater organisms, being an inherent force dictating life histories and affecting biotic interactions within rivers (Robinson et al. 1992, 2002, Lytle and Poff 2004). Consequently, the perception of floods in adaptive management programs must be placed within the framework of disturbance ecology and its theoretical underpinnings (Pickett and White 1985, Poff et al. 1997), especially as experimental floods also affect other habitat features of river ecosystems that are linked with the structure and function of biotic assemblages (Robinson and Uehlinger 2008, Melis 2011). In the most basic sense, experimental floods must be considered in respect to magnitude, duration, and frequency (Lake 2000), and each specific to individual river systems and the landscapes through which they flow.

Disturbance, and flood disturbance in particular, directly influences the population biology, community assembly, and various emergent properties of ecosys tems (Connell 1978, Huston 1979). Two related ecosys tem properties that emerge at both the population and community level in relation to disturbance include resistance (here measured as the relative lack of loss in a specified parameter to floods) and resilience (here measured as the positive slope in a specified parameter vs. time following a flood) (after Webster and Patten 1979). It has been inferred that species populations and community assemblages that have evolved in ecosystems with an inherent disturbance regime would demonstrate greater resistance and resilience to future disturbances than species populations and assemblages adapted to more stable environmental conditions (sensu Connell 1978). This inference is a primary premise behind the observed biotic changes that occur in regulated rivers below dams (Ward and Stanford 1983) and the expected biotic response of these systems to experimental floods (sensu Collie et al. 2004). For instance, biotic assem blages should shift in species composition in response to the change imposed on the habitat template from the flood disturbance (Robinson and Uehlinger 2008).
Although strongly based on disturbance theory, little is known regarding the spatial and temporal dimensions in response patterns of biotic assemblages (species and communities) to a novel disturbance regime, especially in river systems fragmented by large dams. For example, Robinson and Uehlinger (2008) document multiple shifts in community assembly in a regulated river in response to a multiyear flood disturbance regime, and this particular system is further examined in the present paper.

A recent development in the use of experimental floods to improve ecological conditions below dams is to view them as large scale ecosystem experiments (Konrad et al. 2011). Large scale experiments in running waters are few and obviously complex in design as they are typically implemented under the constraints of individ ual adaptive management programs, mechanical limits of dam operations, and human related issues of hydropower and reservoir use (Kondolf and Wilcock 1996, Schmidt et al. 2001). A further current aspect is the interaction of these above constraints with changes in climate and water availability (Konrad et al. 2011). Regardless, many important eco evolutionary insights will be gained as the number of these large scale experiments become implemented and monitored. The information gained will certainly influence future mitigation and management efforts to improve the ecological integrity of running waters in conjunction with using these systems for human needs, and is a growing area of research. Large scale flow experiments, such as used in this paper, are often an integral component of adaptive management programs, al though the goals of such programs vary and may be somewhat removed from attaining a natural flow regime for a particular river system (see Konrad et al. 2011).

The primary objective of this paper was to examine changes in benthic (macroinvertebrate and periphyton) assemblages in response to sequential experimental floods designed to improve trout habitat conditions in the river over a 10 year period. A second objective was to examine temporal changes in response patterns in macroinvertebrate drift and transported organic matter (seston) during individual experimental floods. This paper builds on the results of Robinson and Uehlinger (2008) who summarize population and community level responses to the floods (also see Robinson et al. 2003). Hypotheses tested with the long term data set included: (1) macroinvertebrate community assembly would shift over time in response to changes in the habitat template caused by experimental floods; (2) the abundance of relatively flood resistant invertebrate taxa would in crease in the river over the study period, whereas those taxa less resistant to floods would decrease; and (3) concomitant with shifts in community assembly, macroinvertebrate community resistance and resilience to individual floods would increase over the study period. The hypotheses tested with data from the second objective were that: (1) response patterns in 


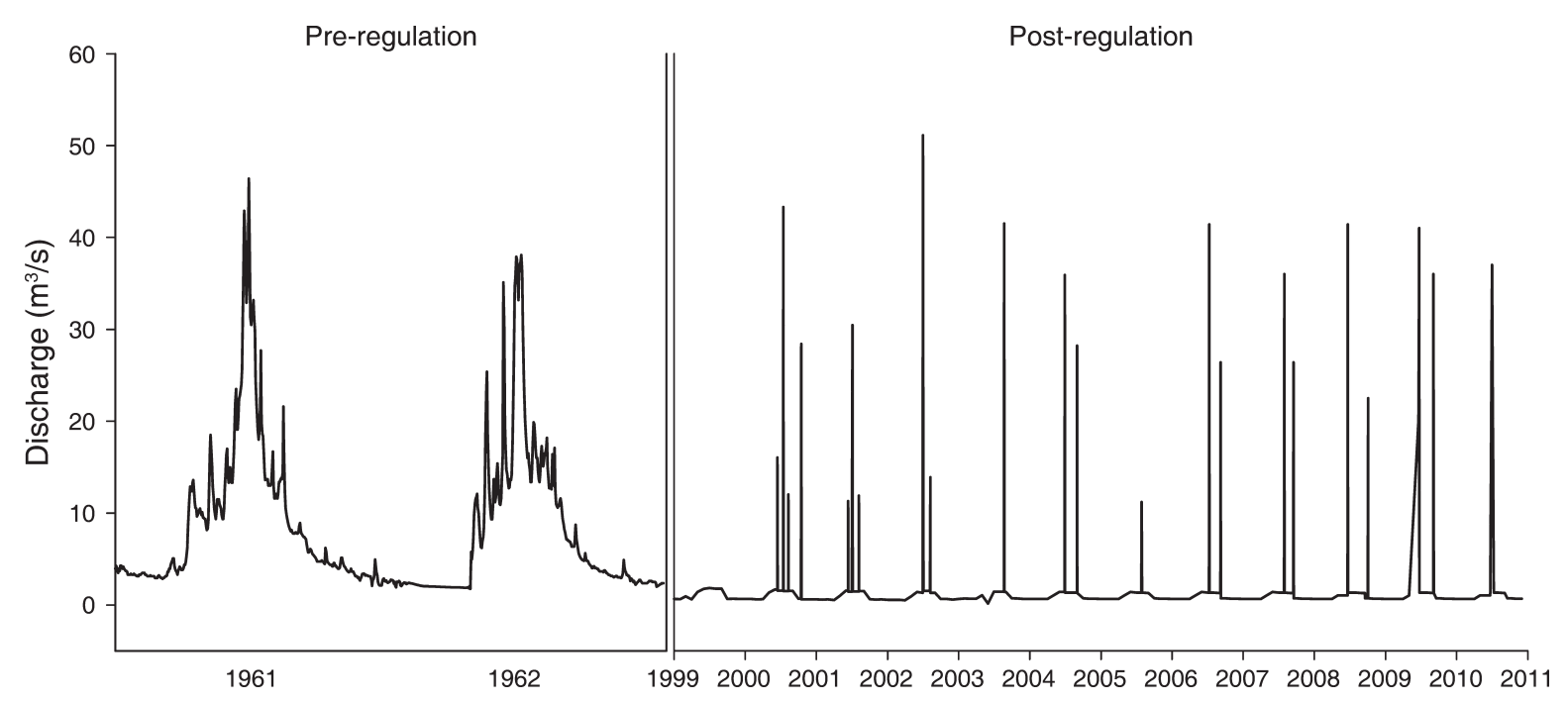

FIG. 1. The flow regime of the Spol River downstream of Livigno Reservoir on the Swiss Italian border, showing two representative years before the dam became operational in 1970, the regulated flow in 1999 without floods, and the experimental flood program after 2000 comprising 22 separate floods.

drift and seston would be related to flood magnitude, and (2) response patterns to floods of similar magni tude would differ between early floods and later floods in concert with changes in macroinvertebrate commu nity assembly.

\section{Methods \\ Site description}

The study was conducted on the Spöl River down stream of Livigno reservoir on the Swiss Italian border $\left(10^{\circ} 11^{\prime} 22^{\prime \prime} \mathrm{E}, 46^{\circ} 36^{\prime} 38^{\prime \prime} \mathrm{N}\right)$. This area is situated within the central part of the inner Alps. The climate is continental, having relatively low precipitation but high seasonal variation in temperature (Barry 1992). Upland vegetation is dominated by coniferous forest (Picea excelsa and Pinus mugo), while alder (Alnus incana) is a common riparian tree along the river margin. The river below Livigno dam (Punt dal Gall) flows through a canyon confined valley within the Swiss National Park for $\sim 5.7 \mathrm{~km}$ before entering the lower Ova Spin reservoir. Elevation at the study reach located $\sim 2.3$ $\mathrm{km}$ downstream of Punt dal Gall is $1660 \mathrm{~m}$ above sea level (a.s.1.). The dam is used for water storage with much of the stored water diverted for hydropower production down valley (see Scheurer and Molinari 2003). The Spöl merges with the Inn River at the town of Zernez, Switzerland, and the Inn is a major tributary of the Danube. Before regulation, the Spöl had a typical snow melt/glacial melt flow regime with high flows in summer and low flows in winter (Fig. 1). Periodic peak flows or floods from heavy rainfall mostly occurred during summer into early autumn and ranged between 20 and $60 \mathrm{~m}^{3} / \mathrm{s}$.

The Spöl is part of a complex hydroelectric scheme (see Scheurer and Molinari 2003). Punt dal Gall dam became operational in 1970 and flow regulation decreased the annual average discharge in the river from 8.6 to $1.0 \mathrm{~m}^{3} / \mathrm{s}$. Two post regulation floods occurred prior to the experimental flood program beginning in 2000, one in 1979 at $42 \mathrm{~m}^{3} / \mathrm{s}$ from heavy rains and another in 1990 at $33 \mathrm{~m}^{3} / \mathrm{s}$ for dam maintenance (Scheurer and Molinari 2003). Regulated residual flows typically average $0.55 \mathrm{~m}^{3} / \mathrm{s}$ in winter and $2.5 \mathrm{~m}^{3} / \mathrm{s}$ in summer using hypolimnetic water from the reservoir (Fig. 1). This residual flow lacked the power to entrain and transport coarse sediments that allowed the riverbed to be clogged with fine sediments (Ortlepp and Mürle 2003), and caused the formation of large pools upstream of lateral debris fans (Mürle et al. 2003). The reduced and stable flows also resulted in dense algal mats, extensive moss beds, and an invertebrate commu nity dominated by Gammarus fossarum (Robinson et al. 2003). Population densities of this crustacean before the experimental floods ranged from 8000 to 15000 individuals $/ \mathrm{m}^{2}$ at the study reach (Robinson and Uehlinger 2008) and it was an important food source for the trout fishery (Ortlepp and Mürle 2003).

The Engadine power company, the Swiss National Park, and state authorities agreed in 1996 to use experimental floods to improve habitat conditions in the river for trout (Scheurer and Molinari 2003). The floods were cost neutral because of the network of reservoirs, aqueducts, and power houses that allowed reallocation of water for power production while maintaining residual flows in the Spöl. Residual flows were further reduced $\left(0.55 \mathrm{~m}^{3} / \mathrm{s}\right.$ winter, $1.45 \mathrm{~m}^{3} / \mathrm{s}$ summer) beginning in 1999 to compensate for water released during each flood (Uehlinger et al. 2003). The experimental flood program began in summer 2000 and based on the ecological results to date has been adopted 
in the regulatory framework of the reservoir ( $\mathrm{T}$. Scheurer, personal communication).

Twenty two separate floods were released between 2000 and the end of 2010 following an adaptive management strategy (Fig. 1). The flood program began with three floods each in 2000 and 2001, then alternating between two floods and a single flood per year from 2002 to 2005. The three floods in 2000 and 2001 consisted of two smaller flows between 12 and $16 \mathrm{~m}^{3} / \mathrm{s}$ in June and August that bounded a higher flow (42 and $55 \mathrm{~m}^{3} / \mathrm{s}$, respectively) in July. One unplanned flood in October 2000 resulted from heavy precipitation that filled the reservoir above storage capacity and caused a $3 \mathrm{~d}$ release of surplus water that peaked at $28 \mathrm{~m}^{3} / \mathrm{s}$. After 2002 , the June flood was eliminated, and in years of two floods, a high flow occurred in July $\left(>30 \mathrm{~m}^{3} / \mathrm{s}\right)$ with a smaller flow in late August/early September $\left(1525 \mathrm{~m}^{3} / \mathrm{s}\right.$; see Fig.1). A 4 d flushing flow was released from 19 to 22 June 2009 that reached a peak flow of $41 \mathrm{~m}^{3} / \mathrm{s}$, and single floods were implemented in $2003\left(41.5 \mathrm{~m}^{3} / \mathrm{s}\right), 2005$ $\left(11.2 \mathrm{~m}^{3} / \mathrm{s}\right)$, and $2010\left(37 \mathrm{~m}^{3} / \mathrm{s}\right)$. Except for the June 2009 flood, each flood lasted between 6 and 8 hours with the step like rising and falling limb being constrained by the physical mechanics of the release valve. The falling limb was designed to be relatively gradual to minimize stranding of fish. Although shorter than most natural floods, the floods were effective in mobilizing bed sediments and reducing algal levels without causing high mortality of fish (see Ortlepp and Mürle 2003, Uehlinger et al. 2003).

\section{Long term monitoring}

A $200 \mathrm{~m}$ long reach $\sim 2.3 \mathrm{~km}$ downstream of the dam was used during the 12 years of study. The study reach was accessed via a national park trail. Discharge was recorded at the gauging station at Livigno Dam by the Federal Office of Hydrology and Geology (Bern, Switzerland). A temperature logger (Minilog; Vemco, Nova Scotia, Canada) was installed at the study site and recorded temperature at $1 \mathrm{~h}$ intervals. Temperature spot recordings were made on each visit as well using the temperature sensor in the field conductivity meter (WTW LF340; Wissenschaftlich Technische Werkstät ten, Weilheim, Germany). The study reach was visited 101 times between 1999 and the end of 2010 for collection of samples. Samples were intentionally collected 13 days before and 12 days after a particular flood, whereas other collections were made every 34 weeks when accessible for long term monitoring pur poses. The overall sampling frequency varied between years, depending on time availability and specific needs of the study.

On each sampling visit, a $1 \mathrm{~L}$ water sample was collected from the thalweg in a polypropylene bottle for analysis of nitrate nitrogen $\left(\mathrm{NO}_{3} \mathrm{~N}\right)$, soluble reactive phosphorus $\left(\mathrm{PO}_{4} \mathrm{P}\right)$, dissolved organic carbon $(\mathrm{DOC})$, and particulate organic carbon (POC) following meth ods detailed in Tockner et al. (1997). In the field, turbidity (nephelometric turbidity units; NTU) (Cos mos, Züllig AG, Switzerland), conductivity $(\mu \mathrm{S} / \mathrm{cm}$ at $20^{\circ} \mathrm{C}$ ) (WTW LF340, Weilheim, Germany), and $\mathrm{pH}$ (WTW pH3110, Weilheim, Germany) were also mea sured using portable meters.

Periphyton was measured by randomly collecting 10 rocks (cobble size) within the study reach on each visit. The rocks were placed in plastic bags, returned to the laboratory, frozen at $20^{\circ} \mathrm{C}$, and processed within three weeks after collection. Periphyton was removed from each rock by scrubbing with a wire brush into a bucket with water, and the $\mathrm{a}, \mathrm{b}$, and $\mathrm{c}$ axis of each rock were measured with a caliper (after Uehlinger 1991). An aliquot of the periphyton suspension was filtered through a glass fiber filter (Whatman GF/F, pre ashed at $450^{\circ} \mathrm{C}$ ) for determination of ash free dry mass (AFDM). The AFDM of each sample was determined by drying the filter at $60^{\circ} \mathrm{C}$, weighing, burning the filter at $500^{\circ} \mathrm{C}$ for $4 \mathrm{~h}$, and then reweighing.

Benthic macroinvertebrates were collected from riffle/ run habitats on each visit using a Hess sampler $(0.045$ $\mathrm{m}^{2}, 250 \mu \mathrm{m}$ mesh, $n=3$ samples). Benthic samples were taken to a standard depth of $20 \mathrm{~cm}$ and all large rocks scrubbed by hand to remove invertebrates before processing. Riffle/run habitats are the most common habitat types in the river because it flows through a canyon confined valley. Samples were stored in plastic bottles and preserved in the field with $70 \%$ ethanol. In the laboratory, macroinvertebrates were handpicked from each sample using a dissecting microscope at $10 \times$, identified to lowest practical taxonomic unit (usually genus), and counted.

\section{Measures collected during floods}

Intensive sampling for invertebrate drift and organic matter in transport (seston) was conducted just before, during, and immediately after six different floods, including three floods in 2001, and single floods in 2002, 2009, and 2010. Flood peaks ranged from $\sim 12 \mathrm{~m}^{3} /$ $\mathrm{s}$ (two small floods in 2001) to $\sim 50 \mathrm{~m}^{3} / \mathrm{s}$. Individual samples were collected using a $400 \mathrm{um}$ mesh nylon net attached to a $15 \times 30 \mathrm{~cm}$ frame at 10 to $30 \mathrm{~min}$ intervals, resulting in 2030 samples being collected for each flood. Due to hysteresis, the more frequent samples were collected during the rising limb into the beginning of the falling limb of each flood, whereas the less frequent samples were collected later in the falling limb. In general, hysteresis is the temporal diminution of a response during a disturbance (sensu Scheffer et al. 2001). Similarly, hysteresis here refers to the increase then falling off of a parameter, e.g., density, in response to changes in discharge over time (i.e., during a flood). Sampling times ranged from $15 \mathrm{~s}$ to 3 min depending on the amount of material in transport at the time of sampling. Velocity was measured at the net aperture using a MiniAir2 velocity meter (Schiltknecht Ag, Gossau, Switzerland) and results are expressed by volume of water filtered. In the laboratory, invertebrates 
were handpicked from each sample (10× magnification) and counted. Drift density values (number per cubic meter) were used in the present paper. The remaining material was used to determine seston as AFDM. Seston AFDM was determined as for periphyton biomass, except that subsamples (quarter or half) were used for large samples. These samples were used to test for changes in the response patterns (e.g., response onset, concentration differences) of drift and organic matter to different floods (magnitude) over time (early vs. late).

\section{Data analysis}

Physico chemical monitoring. Physical and chemical measures were assessed for temporal changes over the course of the study using simple descriptive statistics. No dramatic changes were expected as the experimental protocol only included short increases in discharge, and the water released for each flood was hypolimnetic from the reservoir. These data were used primarily to provide background information on ionic potential, nutrient status for periphyton development, and the overall temperature regime during the study.

Resistance and resilience. Significant temporal shifts in assemblage structure were tested using nonmetric dimensional scaling (NMDS) using both taxa densities and taxa relative abundances from the 101 sampling visits over the course of the study. Resistance of periphyton and macroinvertebrates was assessed by comparing the percentage lack of reduction in periph yton biomass (as AFDM), invertebrate density, and macroinvertebrate richness before and after each flood. These data were tested for differences among floods using simple regression (i.e., plots of resistance vs. flood magnitude). Differences in the resistance of individual taxa were tested using ANOVA with data generated from each flood as replicates. Here, resistance was measured as the percentage lack of reduction in density of a taxon before and after each flood. These data were transformed using the asin(sqrt) function prior to running the ANOVA (Zar 1984).

Resilience was assessed by calculating the recovery slope in periphyton biomass and macroinvertebrate density following each flood. Data for calculation of individual recovery slopes encompassed three to four sampling events following each flood and covered a maximum of 70 post flood days. Only data that met these criteria were used to calculate recovery slopes and included 15 individual floods. Individual slopes were generated from the regression results of density against time. The steeper the slope, the faster the recovery and the higher the resilience. These recovery slopes then were plotted against the percentage loss in periphyton biomass or macroinvertebrate density (i.e., resistance) and against flood year (as a test of changes in resilience between early and later floods).

Measures collected during floods. Drift and seston concentrations were plotted against discharge and time of day. Plots of drift and seston against discharge revealed the different hysteresis patterns between early and later floods, and between floods of different magnitude. Plots of drift and seston against time of day revealed temporal concentration patterns in relation to flood timing between early and later floods, and between floods of different magnitude. Measures of drift and seston during floods also allowed comparison of response patterns of living organisms to that of nonliving organic particles from floods.

\section{RESUlts}

\section{Physico chemical monitoring}

As expected, the water physico chemistry remained fairly stable during the study period due to the hypolimnetic release of water from the reservoir (see Robinson and Uehlinger 2008). Water $\mathrm{pH}$ was neutral and averaged $7.5 \pm 0.4$ (mean $\pm \mathrm{SD}$ ), conductivity was $255 \pm 47 \mu \mathrm{S} / \mathrm{cm}$ (mean $\pm \mathrm{SD}$ ), nitrate $\mathrm{N}$ was $258 \pm 47$ $\mu \mathrm{g} / \mathrm{L}$ (mean $\pm \mathrm{SD}$ ), and soluble reactive phosphorus was $1.0 \pm 1.5 \mu \mathrm{g} / \mathrm{L}$ (mean $\pm \mathrm{SD}$ ). Mean temperature was $7.6^{\circ} \mathrm{C}$ and ranged from $1^{\circ}$ to $2^{\circ} \mathrm{C}$ in winter to $10^{\circ}$ to $12^{\circ} \mathrm{C}$ in summer. Dissolved organic carbon averaged $0.9 \pm 0.5$ $\mathrm{mg} / \mathrm{L}($ mean $\pm \mathrm{SD}$ ) and particulate organic carbon was $0.7 \pm 1.2 \mathrm{mg} / \mathrm{L}($ mean $\pm \mathrm{SD})$.

\section{Community assembly}

In general, the floods reduced the density and taxon richness from pre flood (1999) values (Fig. 2). Average densities decreased from an average 21143 individuals/ $\mathrm{m}^{2}$ in 1999 to 12657 individuals $/ \mathrm{m}^{2}$ in the period 2000 2003 , and to 6975 individuals $/ \mathrm{m}^{2}$ after 2007. Taxon richness averaged 12.4 in 1999 , decreasing to 7.8 from 2000 2003, and to 7.9 after 2007. Evident in richness is an increase between floods to $\sim 12$ taxa after 2007, suggesting new taxa have started colonizing the system (Fig. 2).

The NMDS analysis based on taxon densities and taxon relative abundances revealed significant temporal shifts in community assembly (Fig. 3). Based on taxon densities, assemblage composition was similar in 1999 and 2000, then a shift occurred in 2001 with assemblages being grouped from 2002 to 2006. Another shift occurred in 2007 with assemblages grouping together from 2007 to 2010 (Fig. 3A; stress =13.6). NMDS from the relative abundance data showed a similar pattern with assemblages grouped in 1999 2000, 2001 2002, 2003 2006, and 20072010 (Fig. 3B; stress = 11.5). These data indicate an early period of transition in community assembly between 2001 and 2003 and a later shift between 2006 and 2007.

\section{Resistance and resilience}

Common taxa in the system showed significantly different degrees of resistance to flood disturbances (ANOVA, $P<0.05$; Fig. 4). Gammarids and chiron omids were the least resistant to flood disturbance with densities on average decreasing by $>70 \%$. In contrast, trichopterans showed the most resistance with densities 

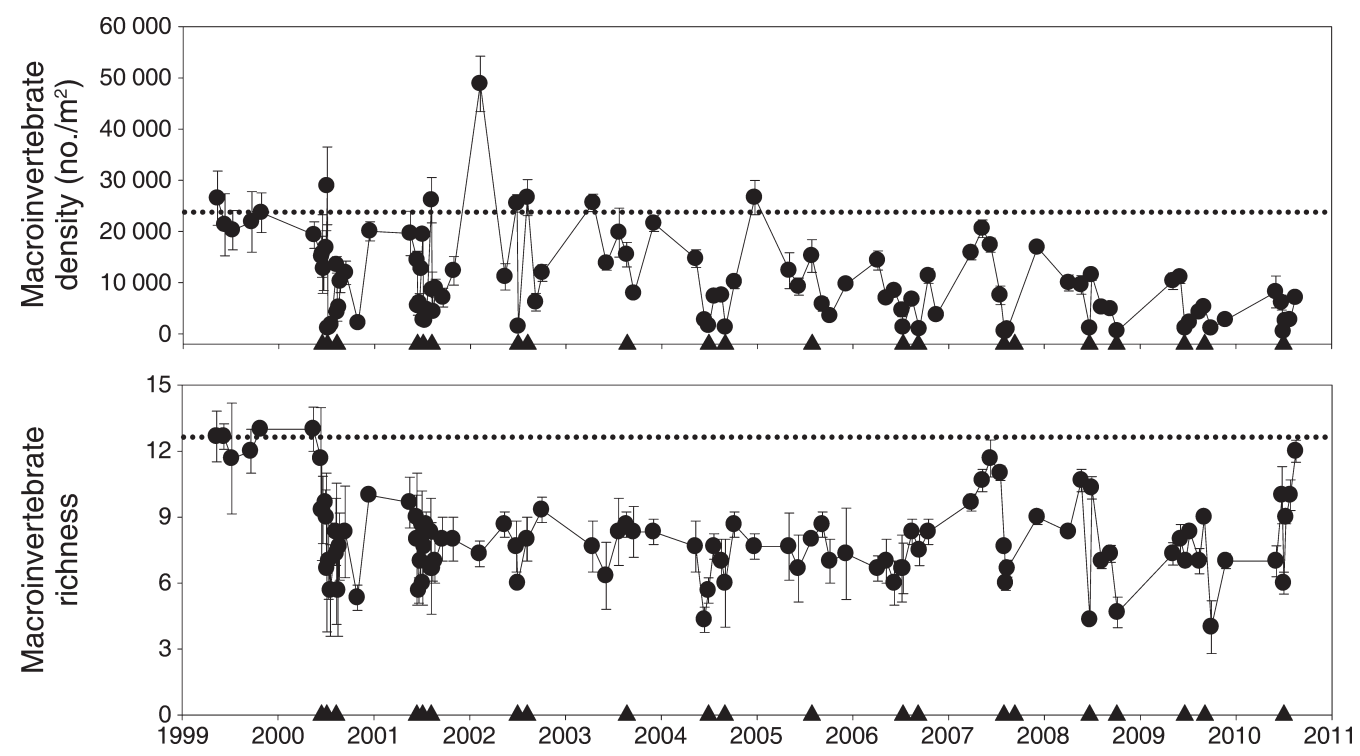

FIG. 2. Plots of average macroinvertebrate density (mean $\pm \mathrm{SE}$ ) and taxon richness from benthic samples collected during the long term flood study. The dashed line represents the average density or richness in the year before the flood program (samples collected in 1999). The triangles on the $x$ axis indicate when a flood occurred.

increasing on average $\sim 10 \%$ following floods. The other common taxa typically showed losses in abundance with densities on average decreasing $2060 \%$ following floods. These latter taxa included baetid mayflies, protonemourid stoneflies, simuliid blackflies, turbellar ians, and other dipterans (mostly Dicranota sp. and empedids).

The relative loss in periphyton biomass following floods ranged from $\sim 20 \%$ to $>90 \%$ with no clear relationship with flood magnitude (Fig. 5A). Both low and extreme losses in periphyton biomass were evident for both smaller $\left(1015 \mathrm{~m}^{3} / \mathrm{s}\right)$ and larger $\left(>25 \mathrm{~m}^{3} / \mathrm{s}\right)$ floods, although most small floods occurred early in the study period. There also was no relationship between the recovery slope in periphyton biomass (resilience) and the relative loss in biomass (Fig. 5B) or the year when the floods occurred (Fig. 5C); i.e., there was no difference in resistance (lack of relative loss) or resilience (recovery slopes) in terms of periphyton AFDM between early and later floods.

The relative loss in macroinvertebrate density in creased with flood magnitude, indicating that resistance was greater for smaller floods $\left(<20 \mathrm{~m}^{3} / \mathrm{s}\right)$ than for larger floods $\left(>25 \mathrm{~m}^{3} / \mathrm{s}\right.$; Fig. 6A). Floods above $25 \mathrm{~m}^{3} / \mathrm{s}$ showed similar values in the relative loss in density with values typically $>75 \%$, whereas losses ranged from $60 \%$ to $70 \%$ for the smaller floods. Notably, the very first flood in the experiment showed no loss in density. The relative loss in taxon richness showed a nonsignificant $(P$ $>0.05$ ) increase with flood magnitude (Fig. 6B). When floods were grouped, however, smaller early floods had on average lower relative loss in richness $(13 \%)$ than early large floods (29\%), and the middle floods had on
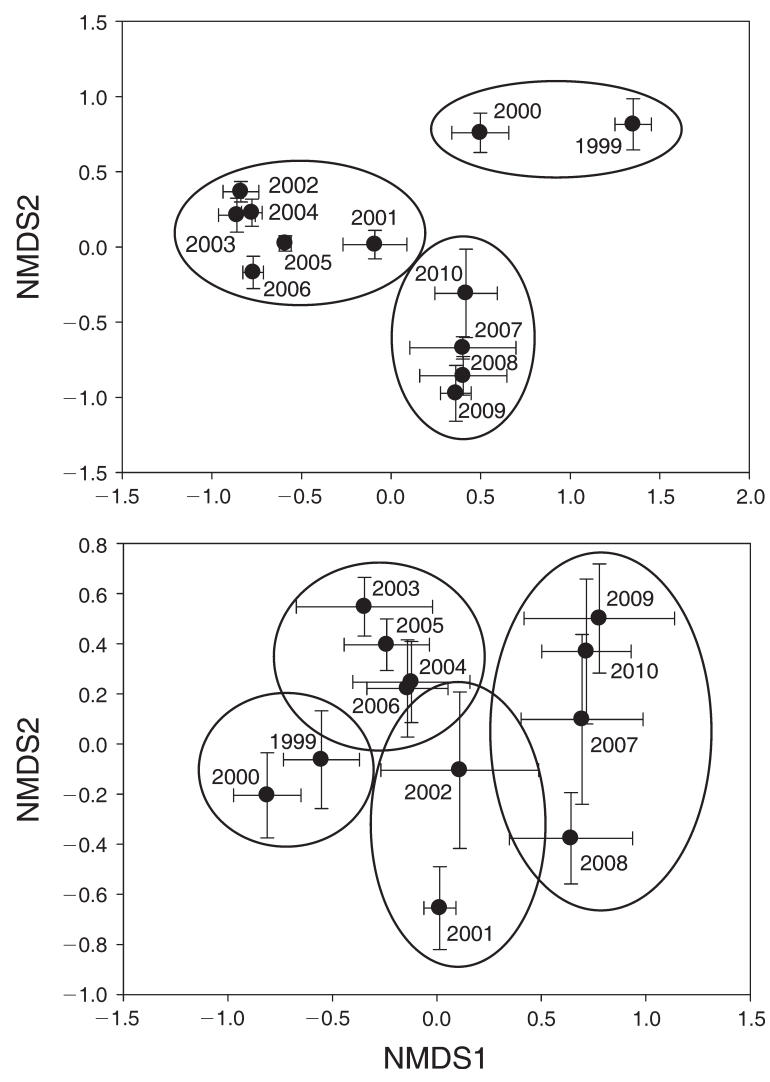

FIG. 3. Nonmetric dimensional scaling (NMDS) plots based on (A) taxon densities and (B) taxon relative abundances using all long term data (101 sampling events) collected during the study. Labeled years in each plot represent the mean $\pm \mathrm{SE}$ for the samples collected in that particular year. Circles were drawn by eye to better illustrate assemblage shifts over the time period of the study. 
FIG. 4. Taxon specific resistance based on the percentage loss in density before and after individual floods during the study period $(n$ 21 floods). Bars represent means + SE. Abbre viations are: TURB, Turbellaria; GAMM, Gam marus fossarum; BAET, Baetis spp.; PROT, Protonemoura sp.; DIPT, Diptera excluding chironomids and simuliids; TRIC, Trichoptera; CHIR, Chironomidae; and SIMU, Simuliidae.

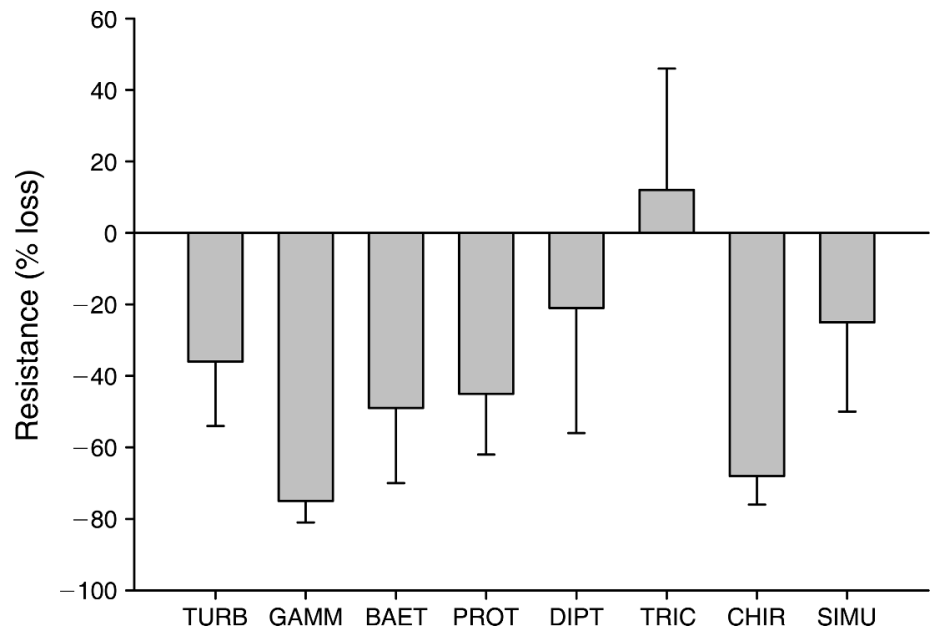

average lower relative loss in richness (13\%) than later floods (35\%; Fig. 6B inset).

Recovery slopes in macroinvertebrate density (resil ience, individuals per square meter per day) tended to increase with the relative loss in density $\left(r^{2}=0.11\right.$; Fig. 7A). However, recovery slopes ranged widely among those floods causing relative density losses $>75 \%$, indicating a wide range in assemblage resilience to different floods. Recovery slopes in macroinvertebrate density, excluding smaller floods $<20 \mathrm{~m}^{3} / \mathrm{s}$, decreased with the year of the experiment $\left(r^{2}=0.60\right.$; Fig. 7B). There was one outlier to this pattern with a flood in 2008 showing a much higher recovery slope than other floods, and with a corresponding large relative loss in density $(90 \%)$.

\section{Responses during floods}

Macroinvertebrates (drift) and organic matter (ses ton) in transport showed mostly similar response patterns during individual floods (Fig. 8). Both drift and seston responded rapidly to increases in flow with both parameters then decreasing as each flood proceed ed, demonstrating the expected hysteresis curve (Fig. 8, left panels). Another common pattern was the occur rence of two drift or seston pulses during a flood. This pattern occurred in the four large floods measured $(>30$ $\left.\mathrm{m}^{3} / \mathrm{s}\right)$, whereas the two small floods $\left(<15 \mathrm{~m}^{3} / \mathrm{s}\right)$ showed only the single response pulse (Fig. 8, right panels). These data suggest an initial response in seston and drift to the increase in flow (flow disturbance responses) and a later response from riverbed movement or enhanced scouring effects as slide slopes collapse into the river (bed mobility or sediment scour response). The flood in 2009 showed a third pattern of a delayed response in drift and seston, which may be a system reaction to the large three day flood earlier that same year in late June.

The density of drifting invertebrates and concentra tion of seston also varied between floods. Peak drift densities ranged from $>300$ individuals $/ \mathrm{m}^{3}$ to $>2000$ individuals $/ \mathrm{m}^{3}$ (Fig. 8), although being unrelated to flood magnitude. The drift pulse was more distinct for the small floods $\left(<15 \mathrm{~m}^{3} / \mathrm{s}\right)$ than the large floods $(>30$ $\mathrm{m}^{3} / \mathrm{s}$ ), mostly because of the second pulse that occurred during large floods. As a consequence, the total number of invertebrates in the drift during each flood was three to nine times greater during large floods (117 304 million invertebrates) than small floods (32 40 million invertebrates), except for the large 2009 flood with 47 million invertebrates being transported downriver. Peak seston concentrations were five to six times greater during large floods $\left(>30 \mathrm{~g} \mathrm{AFDM} / \mathrm{m}^{3}\right)$ than small floods $\left(\sim 6 \mathrm{~g} \mathrm{AFDM} / \mathrm{m}^{3}\right)$, except for the large flood in 2002 in which lower concentrations were observed $(\sim 5 \mathrm{~g}$ AFDM $/ \mathrm{m}^{3}$ ), but these low concentrations occurred during most of the flood period (Fig. 8). The total amount of seston during each flood was three to 30 times more during large floods (9899 kg AFDM in 2001 large flood) than small floods (292 kg AFDM in 2001 small flood). The total amount of seston during large floods was greatest in 2001 at $9899 \mathrm{~kg}$ AFDM, decreasing to $2045 \mathrm{~kg}$ AFDM in 2009 and $2584 \mathrm{~kg}$ AFDM in 2010. An estimated $1263 \mathrm{~kg}$ AFDM of seston was transported in the large 2002 flood.

\section{DisCUSSION}

\section{Shifts in community assembly}

The data support the first hypothesis that community assembly would shift over time in response to the floods. Both the density and richness of macroinvertebrates were significantly affected by the floods, showing reductions in both parameters. The NMDS analysis revealed four groups of years in which assemblages within a group were similar. These groups included the pre flood assemblage (1999 2001), an assemblage in transition from 2001 to 2003, a relatively stable assemblage from 2004 to 2007, and fourth group post 2007. Robinson and Uehlinger (2008) suggested that the initial post flood group was a transition assemblage between alternate community states as inferred from an increase in variance in measured parameters (Carpenter 

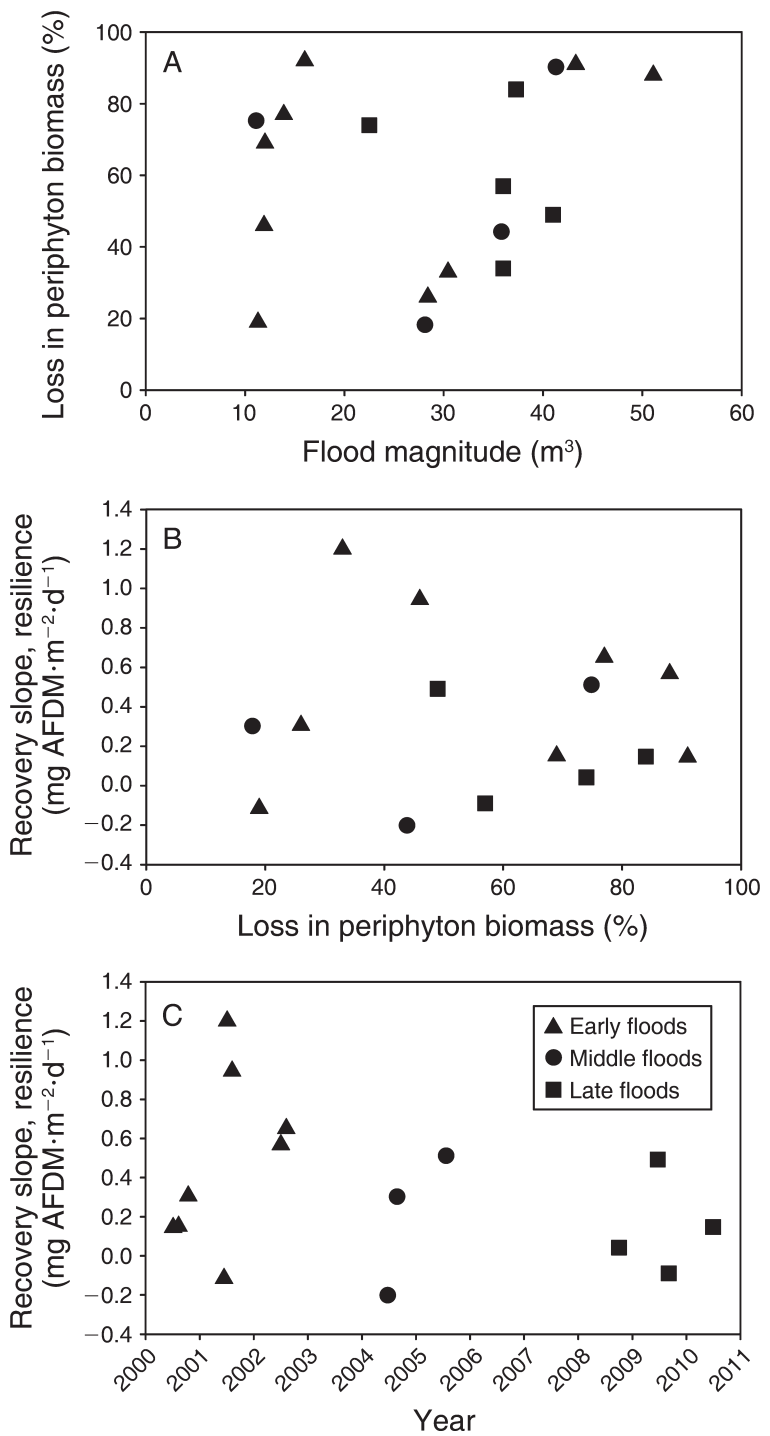

FIG. 5. Scatterplots of (A) percentage loss in periphyton biomass vs. flood magnitude ( $n 18$ floods), (B) recovery slope (resilience) for periphyton vs. the percentage loss in periphyton biomass (resistance; $n \quad 15$ floods), and (C) recovery slope (resilience) for periphyton vs. flood year ( $n$ 15 floods). AFDM is ash free dry mass. Solid triangles are early floods (pre 2003), solid circles are intermediate series floods (2003 2007), and solid circles are later floods (post 2007). The number of floods used in each graph was dependent on data availability.

and Brock 2006). The stable assemblage following 2003 also was reflected in a reduced variance in community measures, although being higher than the pre flood assemblage due to the reset of assemblages following each flood. Assemblage structure following 2007 may also be a period of transition as new taxa become more common in the river system, and the resulting commu nity adjusts to novel biotic interactions. Regardless, the floods have caused a change in the habitat template (sensu Southwood 1977, 1988), which has been reflected in shifts in community assembly over time. Shifts in community assembly following changes in the habitat template have been documented for many kinds of ecosystems (Scheffer et al. 2001), whether from natural factors or those caused by man.

The results suggest that the fragmented character of the river, being relatively isolated between two reservoirs and canyon confined, may cause temporal changes in community assembly to be dispersal limited (see Palmer et al. 1996). As a result of being dispersal limited, shifts in community assembly should be placed in a long term context. For example, the relatively stable assemblage post 2003 was caused by a reduction of less flood resistant taxa, e.g., Gammarus, and an increase of more flood resistant taxa, e.g., Baetis, from the pool of species already inhabiting the river. Robinson and Uehlinger (2008) document a loss in taxon richness during this period, suggesting the taxa remaining were in the system before the experimental flood program was begun but at
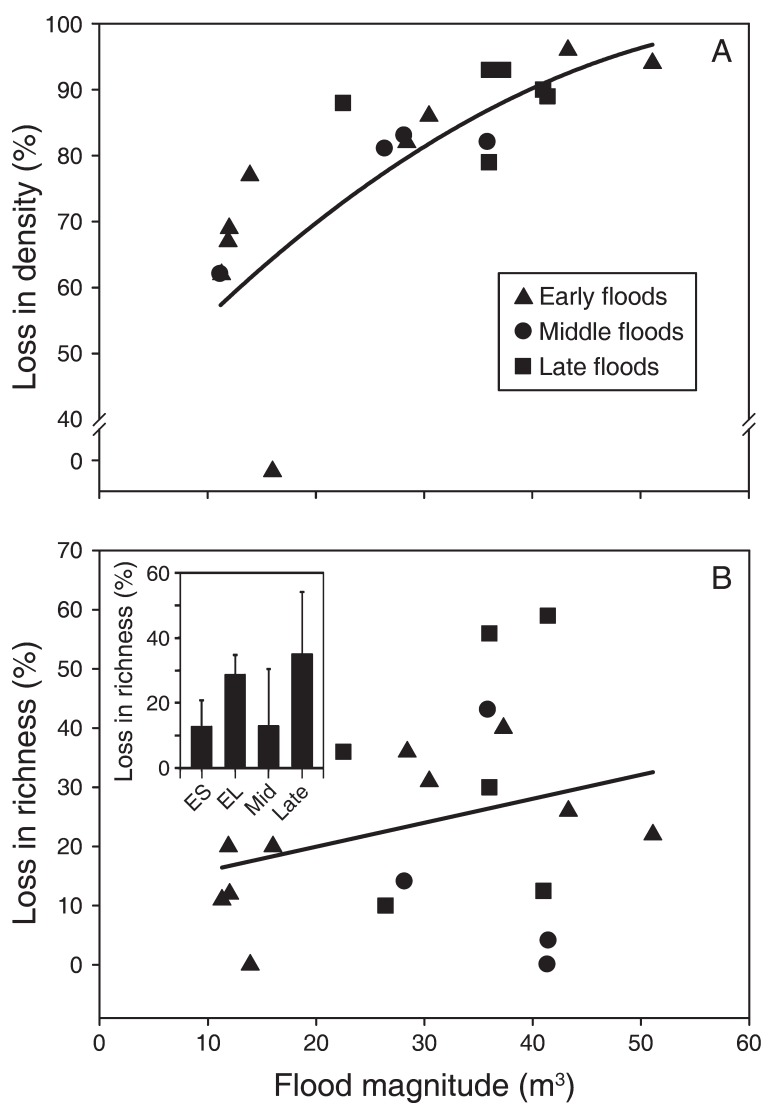

FIG. 6. Scatterplots of (A) percentage loss in macroinver tebrate density vs. flood magnitude ( $n \quad 18$ floods) and (B) percentage loss in macroinvertebrate taxon richness and flood magnitude ( $n \quad 20$ floods) with respective regression lines. Inset in bottom graph shows mean $(+\mathrm{SE})$ percentage loss in richness for different flood types. Key to abbreviations: ES, early small floods, pre 2003 ( $n$ 5); EL, early large floods pre 2003 ( $n$ 5); Mid, middle period floods, 20032007 ( $n$ 4); Late, later floods in the study, post 2007 ( $n$ 6). Solid triangles are early floods (pre 2003), solid circles are middle floods (2003 2007), and solid squares are later floods (post 2007) during the study. 
much lower densities. Gammarus was the dominant invertebrate in the river before the floods, with densities reaching 800015000 individuals $/ \mathrm{m}^{2}$. Taxon richness began to increase in the river after 2007 (see Fig. 2), indicating potentially new taxa are now colonizing the river. For instance, the abundances of simuliid blackflies and leuctrid stoneflies have been increasing substantially in the river since 2007 (C. T. Robinson, unpublished data). Whether these taxa colonized from local scattered refugia, e.g., tributaries, or from regional species pools outside the immediate catchment have yet to be determined. Regardless of source, novel taxa still required a relatively long period of time to colonize and inhabit the river with reproducing populations. Based on invasive species biology (e.g., Sakia et al. 2001), it probably requires multiple colonization at tempts before a new species will have a sustainable population in the river (see With 2002).

\section{Community resistance and resilience}

There were clear shifts in community assembly that were associated with proportional increases in taxa such as baetid mayflies and simuliid blackflies, known to be more disturbance resistant (Robinson and Minshall 1986), than taxa such as the flatworm Crenobia alpina or crustacean Gammarus that decreased in abundance during the study. These changes in community assembly suggest that community resistance to flood disturbance should be increasing over time. The results, however, suggest that community resistance was more a function of flood magnitude than to the community present before each flood. Plausible explanations include that the larger floods, relative to the system, were cata strophic disturbances to stream macroinvertebrates regardless of species specific disturbance related traits; i.e., larger floods are physical forcing events that mobilize bed sediments, scour channels, and alter channel morphology and thereby reduce the densities of all macroinvertebrate taxa in the system (Resh et al. 1988). Catastrophic disturbances are thought to be important reset mechanisms in most ecosystems (Huston 1979, Pickett and White 1985).

Another explanation could be that experimental flood disturbances, although attempting to simulate natural floods, are still outside the realm of the natural flow regime of flood prone rivers in which biota have adapted their life histories to the more predictable flow distur bances (Lytle and Poff 2004). For example, many stream invertebrates have evolved life histories to take into account predictable floods resulting from spring snowmelt (Robinson et al. 1992) or even those systems that appear more flashy in character such as some desert streams (Lytle 2002). A third explanation is that the channel itself may be to a large extent still in physical disequilibrium with the experimental floods, and this causes biotic assemblages to remain in some stage of nonequilibrium as instream habitats continue to change. All three explanations highlight and emphasize the long
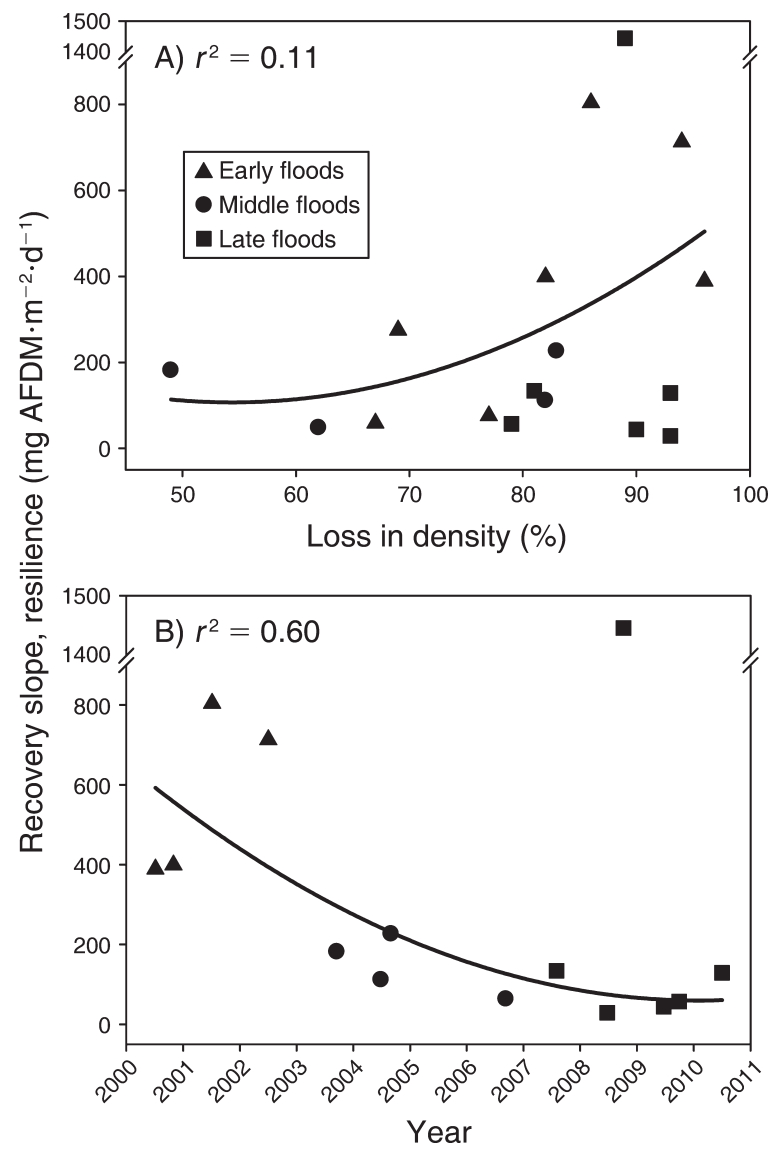

FIG. 7. Scatterplots of (A) recovery slopes (resilience) in macroinvertebrate density vs. percentage lack of loss in density (resistance; $n 19$ floods), and (B) recovery slopes (resilience) in macroinvertebrate density for large floods $>20 \mathrm{~m}^{3} / \mathrm{s}$ vs. time period of study ( $n \quad 14$ floods). AFDM is ash free dry mass. Solid triangles are early floods (pre 2003), solid circles are middle period floods (2003 2007), and solid squares are later floods (post 2007).

term nature of using experimental floods in regulated rivers, especially as upstream dams mitigate other physical properties of these rivers. Also, these large scale experiments encompass various goals from an adaptive management perspective, and these must be taken into account when assessing such studies (see Konrad et al. 2011). Importantly here, the results strongly suggest that a long term perspective is needed because of the time of colonization for species from outside the system and the time needed for these species to adapt to the novel flow regime.

In contrast, smaller floods above a certain threshold, respective of the system, showed that the macroinverte brate community was more resistant to the flow disturbance than those affected by large floods. Densi ties were reduced following the smaller floods, but much less so than following the large catastrophic floods. These smaller floods still had the capacity to reduce periphyton biomass in the river, a desired management 

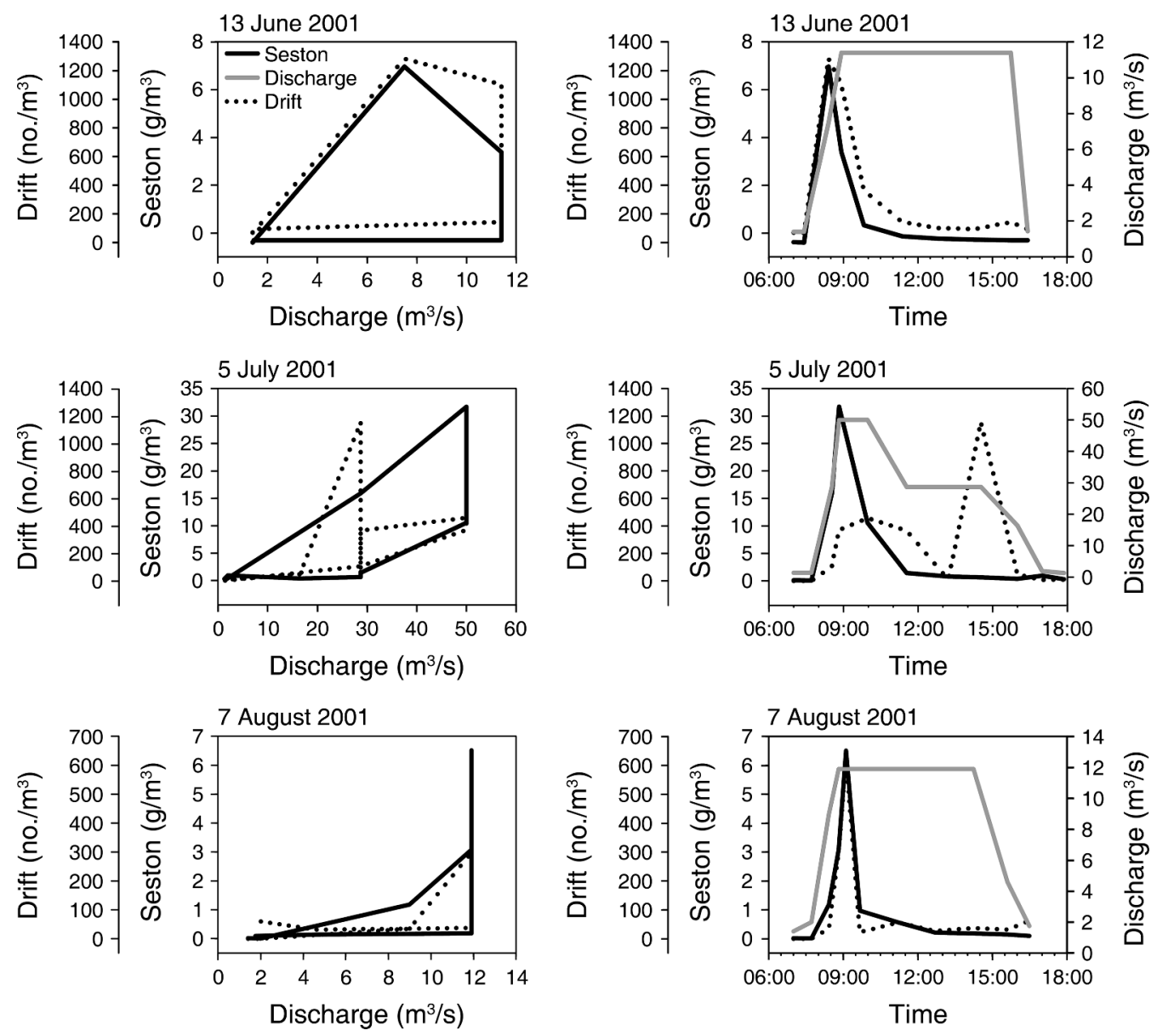

FIG. 8. Line graphs of macroinvertebrate drift and seston concentrations plotted against discharge (left panels), showing hysteresis patterns during each flood, and time of day (right panels), showing temporal response patterns for six different floods during the study period. Floods encompassed four early floods (2001 2002) and two late floods (2009 2010). Two of the early floods were small floods $\sim 12 \mathrm{~m}^{3} / \mathrm{s}$, and the others were all large floods $>30 \mathrm{~m}^{3} / \mathrm{s}$. (Note that the figure continues on the next page.)

objective to improve habitat conditions for the trout fishery (Ortlepp and Mürle 2003). These results empha size the importance of an adaptive management program that takes into account changes in management objectives as flood effects are monitored over time. Larger floods were used initially in the Spöl to restructure channel morphology, scour large sediment deposits from adjacent scree slopes, and improve bed conditions for redd development by brown trout (Scheurer and Molinari 2003). This essentially means a change in the habitat template of the river to that of a more natural system (sensu Poff et al. 1997). After a number of successful large flood events, these manage ment objectives were essentially met, and a new flood regime is currently being adopted to maintain those ecological benefits to the river. The new flood program is testing the use of smaller floods that still mobilize bed sediments without flushing fines and reduce periphyton biomass but have less impact on macroinvertebrate communities and the fishery in general.
Community resilience was quite variable, although showing a general decrease with later floods. Resilience was also poorly related to community resistance in this system $\left(r^{2}=0.11 ;\right.$ Fig. $\left.7 \mathrm{~A}\right)$. The variability in resilience may be related to the seasonal timing of floods, but this was not examined in the current study. For example, seasonal changes in macroinvertebrate abundances or the presence of aerial adults in the catchment during a flood may affect the measured resilience of the community. Aerial adults may reproduce and lay eggs in the system following flood disturbance and thereby enhance overall system resilience (Winterbourn 1997). The decrease in community resilience with later floods suggests that the larger floods are indeed acting as a catastrophic event in this regulated river. These large floods had a large effect on reducing macroinvertebrate densities in the river with a concomitant influence on community resilience. Even though the community assembly itself consists mostly of disturbance resistant taxa, once these taxa are reduced beyond a certain density threshold, the resilience of the community is 

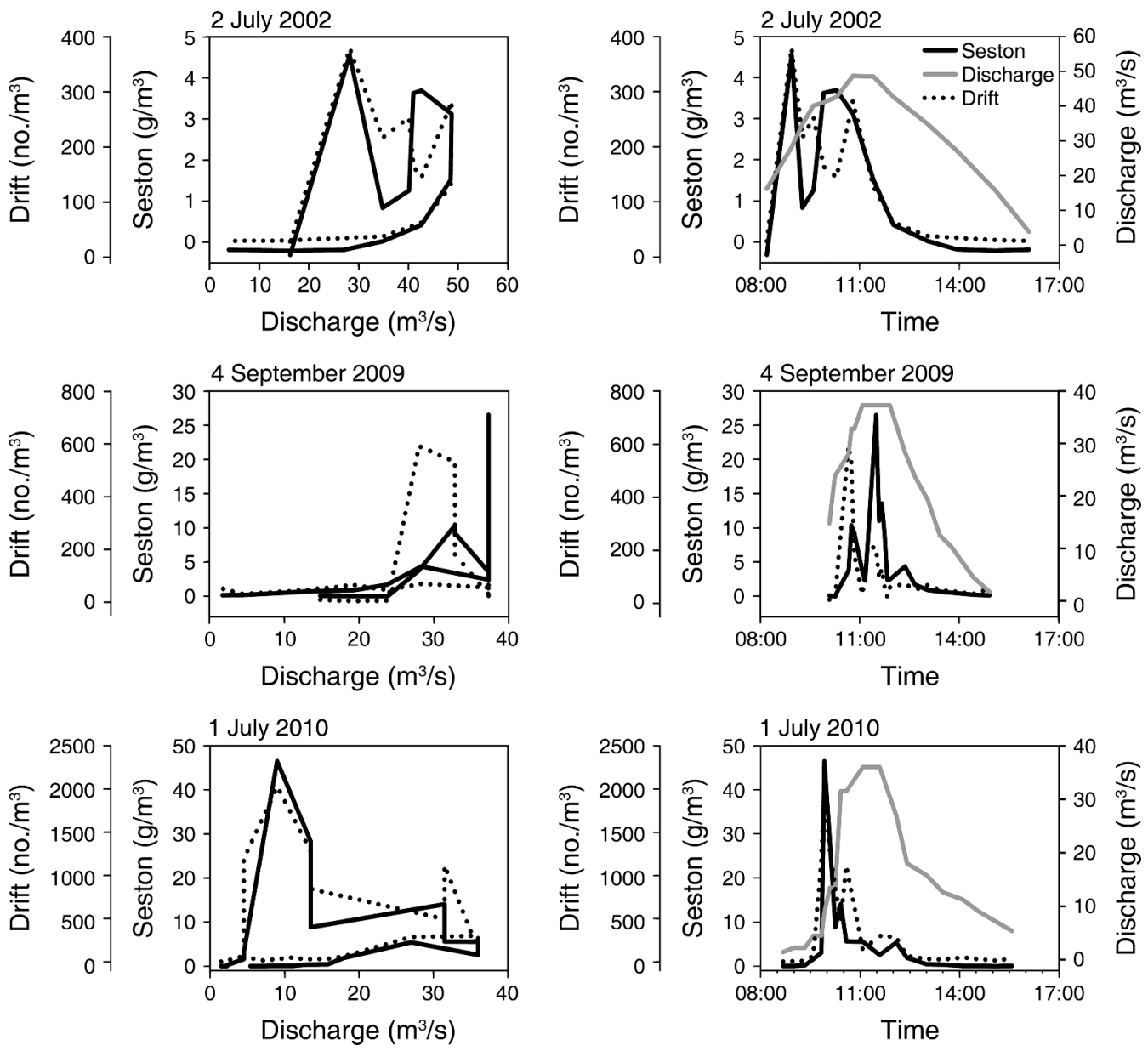

FIG. 8. Continued.

constrained. These results strongly argue for an adaptive management program that alters the experimental flood regime to take into account long term abiotic and biotic changes in the river.

\section{Drift and seston patterns during floods}

Drift and seston showed a variety of response patterns to the different floods that were related to flood magnitude and flood year. Both drift and seston typically responded quite rapidly by increasing in concentration during the rising limb of each flood. Imbert and Perry (2000) observed a similar drift response to floods. The similar pattern between drift and seston suggests that the response was probably a passive function with increases in flow. Drift and seston peaked once during the two examined smaller floods, but usually showed at least two peaks during the larger floods. The initial peak in drift and seston was likely organisms and organic particles associated with surface sediments, whereas secondary peaks during the larger floods were related to mobilization of bed sediments or bank failures from erosion that increased the scouring of bed sediments (see Robinson et al. 2004). Bank failures also provided inputs of organic matter into the river that were reflected in higher seston concentrations. The timing of these secondary peaks differed between the larger floods and may constitute an additional unpre dictable disturbance to organisms during floods. The results highlight significant differences in response dynamics between floods of different magnitude that is reflected in the degree of disturbance caused by different floods.

The floods transported large numbers of organisms and quantities of organic matter. The number of drifting macroinvertebrates ranged from 32 to $>300$ million individuals during a flood, whereas the amount of seston ranged from 300 to $\sim 10000 \mathrm{~kg}$ dry mass (see Robinson et al. 2004). Larger floods clearly transported greater numbers of organisms and amounts of seston than the smaller floods. Among the larger floods, the 2001 flood transported three to seven times more organisms and four to eight times more seston than the later floods. The large 2001 flood was a long duration, high magnitude flood, whereas the other large floods were lesser magnitude, shorter duration floods $(2009,2010)$ or a short duration, high magnitude flood (2002). These 
results confirm that flood magnitude and duration are important disturbance components when implementing an experimental flood program (Konrad et al. 2011). Both parameters must be considered when implementing experimental floods from an adaptive management perspective. The flood strategy for the Spöl River now comprises floods of lesser magnitude $\left(\sim 2530 \mathrm{~m}^{3} / \mathrm{s}\right)$ and similar duration (approximately two hour peak flow, total duration approximately eight hours) as the floods in 2009 and 2010 (T. Scheurer, personal communication). These new experimental floods are designed to reduce periphyton biomass in the river, while minimizing the amount of fines in transport that are important for the development of redds by trout. Furthermore, these floods will likely reduce the loss in invertebrates, i.e., increase resistance, and also increase the resilience of the macroinvertebrate assemblage in the river.

\section{ACKNOWLEDGMENTS}

This project was initiated in collaboration with $\mathrm{U}$. Uehlinger, T. Scheurer, and M. T. Monaghan. Field and laboratory assistance over the years was provided especially by C. Jolidon and $\mathrm{S}$. Blaser as well as numerous undergraduate and graduate students and research visitors. Analysis of water samples was completed by R. Illi, Analytical Lab, Eawag. Logistical support for conducting research in the Swiss National Park was provided by F. Filli, SNP; P. Molinari, Engadiner Kraftwerk; and T. Scheurer, SCNAT. Partial funding of the project was provided by the Swiss National Park and Department of Game and Fish, Graubunden. The paper is a contribution of the AlpWaterScarce project (www.alpwaterscarce.eu), a member of the Alpine Space Program. The author especially thanks two anonymous reviewers for constructive comments that improved the paper.

\section{Literature Cited}

Arthington, A. H., S. E. Bunn, N. L. Poff, and R. J. Naiman. 2006. The challenge of providing environmental flow rules to sustain river ecosystems. Ecological Applications 16:1311 1318.

Barry, R. C. 1992. Mountain weather and climate. Routledge, London, UK.

Bejarano, M. D., C. Nilsson, M. Gonzalez del Tanago, and M. Marchamalo. 2011. Responses of riparian trees and shrubs to flow regulation along a boreal stream in northern Sweden. Freshwater Biology 56:853 866.

Cardinale, S. R., M. A. Palmer, A. R. Ives, and S. S. Brooks. 2005. Diversity productivity relationships in streams vary as a function of the natural disturbance regime. Ecology 86:716 726 .

Carpenter, S. R., and W. A. Brock. 2006. Rising variance: a leading indicator of ecological transition. Ecology Letters $86: 716726$.

Collie, J. S., K. Richardson, and J. H. Steele. 2004. Regime shifts: Can ecological theory illuminate the mechanisms? Progress in Oceanography 60:281 302.

Connell, J. H. 1978. Diversity in tropical rain forests and coral reefs. Science 199:1302 1310

Cross, W. F., C. V. Baxter, K. C. Donner, E. J. Rosi Marshall, T. A. Kennedy, R. O. Hall, Jr., H. A. Wellard Kelly, and R. Scott Rogers. 2011. Ecosystem ecology meets adaptive management: food web response to a controlled flood on the Colorado River, Glen Canyon. Ecological Applications 21:2016 2033.

Dudgeon, D. 2000. Large scale hydrological changes in tropical Asia: prospects for riverine biodiversity. BioScience 50:793 806.
Graf, W. L. 2006. Downstream hydrologic and geomorphic effects of large dams on American rivers. Geomorphology 79:336 360 .

Huston, M. 1979. A general hypothesis of species diversity. American Naturalist 113:81 101.

Imbert, J. B., and J. A. Perry. 2000. Drift and benthic invertebrate responses to stepwise and abrupt increases in non scouring flow. Hydrobiologia 436:191 208.

Johnson, P. T. J., J. D. Olden, and M. J. Vander Zanden. 2008. Dam invaders: impoundments facilitate biological invasions into freshwaters. Frontiers in Ecology and Environment 6:357 363 .

Junk, W. J., P. B. Bayley, and R. E. Sparks. 1989. The flood pulse concept in river floodplain systems. Pages 110127 in D. P. Dodge, editor. Proceedings of the Large River Symposium Canadian Special Publication in Fisheries and Aquatic Sciences 106.

Kondolf, G. M., and P. R. Wilcock. 1996. The flushing flow problem: defining and evaluating objectives. Water Resourc es Research 32:2589 2599.

Konrad, C., et al. 2011. Large scale flow experiments in managing water resources. BioScience 61:948 959.

Lake, P. S. 2000. Disturbance, patchiness, and diversity in streams. Journal of the North American Benthological Society 19:573 592 .

Lytle, D. A. 2002. Flash floods and aquatic insect life history evolution: evaluation of multiple models. Ecology 83:370 385.

Lytle, D. A., and N. L. Poff. 2004. Adaptation to natural flow regimes. Trends in Ecology and Evolution 19:94 100.

Melis, T. S., editor. 2011. Effects of three high flow experiments on the Colorado River ecosystem downstream from Glen Canyon Dam, Arizona. U.S. Geological Survey Circular 1366.

Merritt, D. M., and E. E. Wohl. 2006. Plant dispersal along rivers fragmented by dams. River Research and Applications 22:1 26.

Monaghan, M. T., P. Spaak, C. T. Robinson, and J. V. Ward. 2002. Population genetic structure of 3 alpine stream insects: influences of gene flow, demographics, and habitat fragmen tation. Journal of the North American Benthological Society 21:114 131 .

Mueller, N. 1995. River dynamics and floodplain vegetation and their alterations due to human impact. Archiv fur Hydrobiologie 101:477 512 .

Murle, U., J. Ortlepp, and M. Zahner. 2003. Use of experimental flooding to enhance river integrity below a large dam: sediment processes and changes in geomorphol ogy, habitat structure and riparian vegetation. Aquatic Sciences 65:191 198.

Nilsson, C., C. A. Reidy, M. Dynesius, and C. Revenga. 2005. Fragmentation and flow regulation of the world's large river systems. Science 308:405 408.

Olden, J. D., and R. J. Naiman. 2010. Incorporating thermal regimes into environmental flows assessments: modifying dam operations to restore freshwater ecosystem integrity. Freshwater Biology 55:86 107.

Ortlepp, J., and U. Murle. 2003. Effects of experimental flooding on brown trout (Salmo trutta fario L.): the Spol River, Swiss National Park. Aquatic Sciences 65:232 238.

Palmer, M. A., J. D. Allan, and C. A. Butman. 1996. Dispersal as a regional process affecting the local dynamics of marine and stream benthic invertebrates. Trends in Ecology and Evolution 11:322 326.

Pickett, S. T. A., and P. S. White. 1985. The ecology of natural disturbance and patch dynamics. Academic Press, New York, New York, USA.

Poff, N. L., J. D. Allan, M. B. Bain, J. R. Karr, K. L. Prestegaard, B. D. Richter, R. E. Sparks, and J. C. Stromberg. 1997. The natural flow regime. BioScience 47:769 784 . 
Power, M. E., W. E. Dietrich, and J. C. Finlay. 1996. Dams and downstream aquatic biodiversity: potential food web conse quences of hydrologic and geomorphic change. Environmen tal Management 20:887 895.

Resh, V. H., A. V. Brown, A. P. Covich, M. E. Gurtz, H. W. Li, G. W. Minshall, S. R. Reice, A. L. Sheldon, J. B. Wallace, and R. C. Wissmar. 1988. The role of disturbance in stream ecology. Journal of the North American Benthological Society 7:433 455 .

Robinson, C. T., S. Aebischer, and U. Uehlinger. 2004. Immediate and habitat specific responses of macroinverte brates to sequential experimental floods. Journal of the North American Benthological Society 23:853 867.

Robinson, C. T., and G. W. Minshall. 1986. Effects of disturbance frequency on stream benthic community struc ture in relation to canopy cover and season. Journal of the North American Benthological Society 5:237 248.

Robinson, C. T., L. R. Reed, and G. W. Minshall. 1992. Influence of flow regime on life history, production, and genetic structure of Baetis bicaudatus (Ephemeroptera) and Hesperoperla pacifica (Plecoptera). Journal of the North American Benthological Society 11:278 289.

Robinson, C. T., K. Tockner, and J. V. Ward. 2002. The fauna of dynamic riverine landscapes. Freshwater Biology 47:661 677.

Robinson, C. T., and U. Uehlinger. 2008. Experimental floods cause ecosystem regime shift in a regulated river. Ecological Applications 18:511 526.

Robinson, C. T., U. Uehlinger, and M. T. Monaghan. 2003. Effects of a multi year experimental flood regime on macroinvertebrates downstream of a reservoir. Aquatic Sciences 65:210 222.

Sakia, A. K., et al. 2001. The population biology of invasive species. Annual Review of Ecology and Systematics 32:305 332.

Scheffer, M., S. Carpenter, J. A. Foley, C. Folke, and B. Walker. 2001. Catastrophic shifts in ecosystems. Nature 4113:591 596.

Scheurer, T., and P. Molinari. 2003. Experimental floods in the River Spol (Swiss National Park): framework, objectives and design. Aquatic Sciences 65:183 190.

Schmidt, J. C., R. A. Parnell, P. E. Grams, J. E. Hazel, M. A. Kaplinski, L. E. Stevens, and T. L. Hoffnagle. 2001. The 1996 controlled flood in Grand Canyon: flow, sediment transport, and geomorphic change. Ecological Applications 11:657 671 .
Southwood, T. R. E. 1977. Habitat, the templet for ecological strategies. Journal of Animal Ecology 46:337 365.

Southwood, T. R. E. 1988. Tactics, strategies, and templets. Oikos 52:3 18.

Tockner, K., F. Malard, P. Burgherr, C. T. Robinson, U. Uehlinger, R. Zah, and J. V. Ward. 1997. Physico chemical characterization of channel types in a glacial floodplain ecosystem (Val Roseg, Switzerland). Archiv fur Hydro biologie 140:433 463 .

Uehlinger, U. 1991. Spatial temporal variability of the periphyton biomass in a prealpine river (Necker, Switzer land). Archiv fur Hydrobiologie 123:219 237.

Uehlinger, U., B. Kawecka, and C. T. Robinson. 2003. Effects of experimental floods on periphyton and stream metabolism below a high dam in the Swiss Alps (River Spol). Aquatic Sciences 65:199 209.

Vannote, R. L., G. W. Minshall, K. W. Cummins, J. R. Sedell, and C. E. Cushing. 1980. The river continuum concept. Canadian Journal of Fisheries and Aquatic Sciences 37:130 137.

Vannote, R. L., and B. W. Sweeney. 1980. Geographic analysis of thermal equilibria: a conceptual model for evaluating the effect of natural and modified thermal regimes on aquatic insect communities. American Naturalist 115:667 695.

Ward, J. V., and J. A. Stanford. 1979. The ecology of regulated streams. Plenum Press, New York, New York, USA.

Ward, J. V., and J. A. Stanford. 1983. The serial discontinuity concept of lotic ecosystems. Pages 2942 in T. D. Fontaine and S. M. Bartell, editors. Dynamics of lotic ecosystems. Ann Arbor Science, Ann Arbor, Michigan, USA.

Ward, J. V., and J. A. Stanford. 1995. The serial discontinuity concept: extending the model to floodplain rivers. Regulated Rivers: Research and Management 10:159 168.

Webster, J. R., and B. C. Patten. 1979. Effects of watershed perturbation on stream potassium and calcium dynamics. Ecological Monographs 49:51 72.

Winterbourn, M. J. 1997. New Zealand mountain stream communities: stable yet disturbed. Pages 3154 in B. Streit, T. Stadler, and C. M. Lively, editors. Evolutionary ecology of freshwater animals. Birkhauser, Berlin, Germany.

With, K. A. 2002. The landscape ecology of invasive spread. Conservation Biology 16:1192 1203.

Zar, J. H. 1984. Biostatistical analysis. Second edition. Prentice Hall, Englewood Cliffs, New Jersey, USA. 